\title{
光過敏症ラットの心電図所見と血清電解質の変化
}

\author{
礒 部 明 彦*, 加 藤 純 二**, 木 村 修 一* \\ * 東北大学農学部栄盖化学教室 ${ }^{* *}$ 東北大学抗酸菌病研究所肺癌教室
}

\section{Changes of Electrocardiogram Observations and Serum Electrolytes on the Hypersensitive Rats}

\author{
Akihiko ISOBE,* Juneji KHATO** and Shuichi KIMURA* \\ * Laboratory of Nutrition, Faculty of Agriculture, Tohoku University, Sendai \\ ** Department of Oncology, Research Institute for Tuberculosis, \\ Leprosy and Cancer, Tohoku University, Sendai
}

In the previous paper it was suggested that the hypersensitiveness of the photodynamic sensitization was mainly responsible for myocardial damage.

In order to confirm this speculation, the electrocardiographic observation was carried out.

The electrocardiogram showed closely resemble to a pattern of the hyperkalemia.

Then, the levels of serum electrolytes were determined on the female rats, and the high level of potassium in serum was observed.

These facts suggested that the hemolysis was induced by hypersensitiveness of the photodynamic sensitization with pheophorbide.

(Received June 14, 1976)

著者ら"1は, 先に光過敏症の成因解明のため, 病態生 理学的, 特に, 脳血管透過性の亢進の有無について検討 したところ, 有意の変動は認められず, むしろ心筋障害 あるいは溶血による血清電解質異常による急速死の可能 性が示唆された。そこで今回, 光過敏症ラットについ て，心奄困検查および血清電解質の測定を行ない，光過 敏症による死因を考えるうえで重要な異常所見を認めた のでここに報告する。

\section{実 験 方 法}

\section{1. 心電図撮影}

光過敏症の原因物質であるへオホーバイド $25 \mathrm{mg} / \mathrm{kg}$ 体重をジメチルスルホキサイド(以下 DMSO と略す) $0.5 \mathrm{ml}$ に溶解し, 約 $200 \mathrm{~g}$ のウィスター系雌ラットの 腹腔内に注射し， 5 時間， 1 万ルックスの光照射を行な

†光力学的物質による過敏症成立とそのメカニズム (第 4 報)

Appearance of Hypersensitiveness by Photodynamic Agent and Its Physiological Mechanism (Part IV)

* T 980 宮城県仙台市堤通雨宮町 1-1

** $\bar{\top} 980$ 宮城県仙台市広瀬町 4-12
い光過敏症ラットを作製した2)。また，正常および光過 敏症ラットにペントバルビタール（アボットラボラトリ 一ズ製造）を $35 \mathrm{mg} / \mathrm{kg}$ 腹腔内に注射し，ラットを水平 背位固定し，上下肢の皮下に電極針を刺入し，標準肢誘

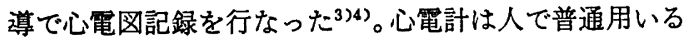
もの (福田電子株式会社製) で，感度は $1 \mathrm{mV}, 10 \mathrm{~mm}$, 速度は $25 \mathrm{~mm} /$ 秒，扰よび $50 \mathrm{~mm} /$ 秒で行なった。同時 に, 熱電対式温度計（宝熱電対器械株式会社製）を用い, 直腸内温度を測定し, 肉眼的に呼吸数を測定した。

\section{2. 血清電解临の測定}

正常および光過敏症ラットをエチルエーテルで麻醉 乙, 開腹し腹部大動脈より血液を採取し， $37^{\circ} \mathrm{C}, 1$ 時間 静固し, 凝固した血夜を $3,000 \mathrm{rpm}, 15$ 分間遠心して血 清を得た。採血には, シリコン処理ディスポーザブルシ リンジ 19G 注射針（仁丹体温計株式会社製）を用い た。

血清電解質の測定については, ナトリウム, カリウ ム, カルシウム, 塩素, リンは炎色比色定量法により, マグネシウムはアルカリ性でキシリジルブルーI 吕結合 させて，515 nm に吸収極大をるつ赤紫色の水溶性キレ ー ${ }^{5)}$ を測定して行ない, 試薬は和光純薬工業株式会社 製キットを使用した。 
結果と考察

1. 心電図の所見について

心電図測定は, 光過敏症ラットの死因について,なん らかの情報, 特に, 心臓循環器系異常の動態的把握に適 していると考えられる6。

Fig. 1 は正常ラットの心電図の第 $1 ， 2 ， 3$ 各誘導を 示す。ここで，心房波である $\mathrm{P}$ 波が正常に出現し，P波 からQ波までの 房室間興奮 伝導時間, QRS の心室内興 淘伝達, ST の心室内興畜の持続, $\mathrm{T}$ の心室内興奮の終 止, QT (QRS の起始部からTの終末部) の距離等, 寸 べて正常であることが観察された。

心拍数は 320 330/分でほぼ正常範团にあり7)，体温 は $37.5^{\circ} \mathrm{C}$, 呼吸数は 85 90 回/分であった。

1) 実験 1 正常ラットの心電図に対して, 光過敏症 ラットでは, 光照射 5 時間後の心電図測定開始時には,

Fig. 2 に示すごとく，体温はすでに約 $28^{\circ} \mathrm{C}$ まで下降し ていた。しかしながら，心電図波形には特に変化が認め られなかった。

Fig. 3 は測定開始25分後の心電図であるが，QRS の voltage が著しく低下し，第 2,3 誘導で $\mathrm{S}$ deflection が增加し，ST の上昇が著明となった。Fig. 4 は Fig. 3 撮影後 5 分, 寸なわち, 心電図撮影開始後 30 分の心電図 である。P波と QRS との間に一定の関係がみられず, 完全房室ブロックであり，しかも，QRS の幅が広く不 規則な心室性調律がみられる。Fig. 5 はその数分後の心

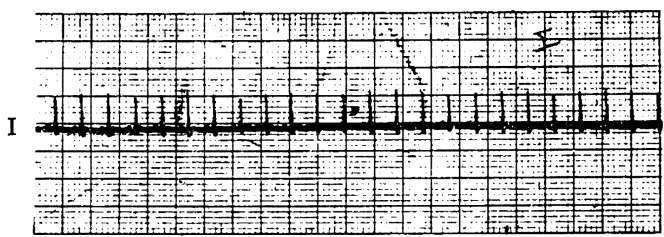

II
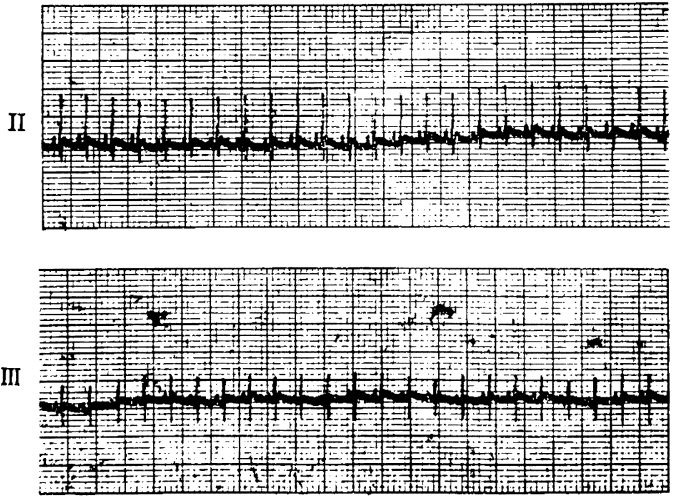

Fig. 1. Electrocardiograms of normal rat.

I : the first lead, II : the second lead, III : the third lead, voltage : $1 \mathrm{mV}$, velocity : $25 \mathrm{~mm} / \mathrm{sec}$.
電図であるが，ここでは $\mathrm{P}$ 波が消失し，幅の広いQRS 波が不規則に出現し, 高カリウム血症の心電図所見によ く一致している。な报，これはラットの死亡直前の心電 四である。

2）実験 2 つぎに，このような心電図変化に光照射 が確かに関与しているかどらか検討を試みた。へオホー

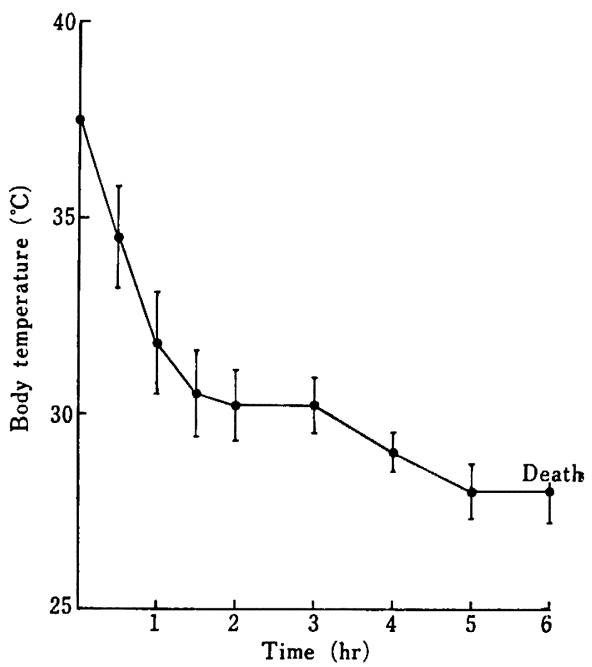

Fig. 2. Changes of body temperature on the hypersensitive rats.

Symbols indicate the geometrical mean and S.D. of three rats.
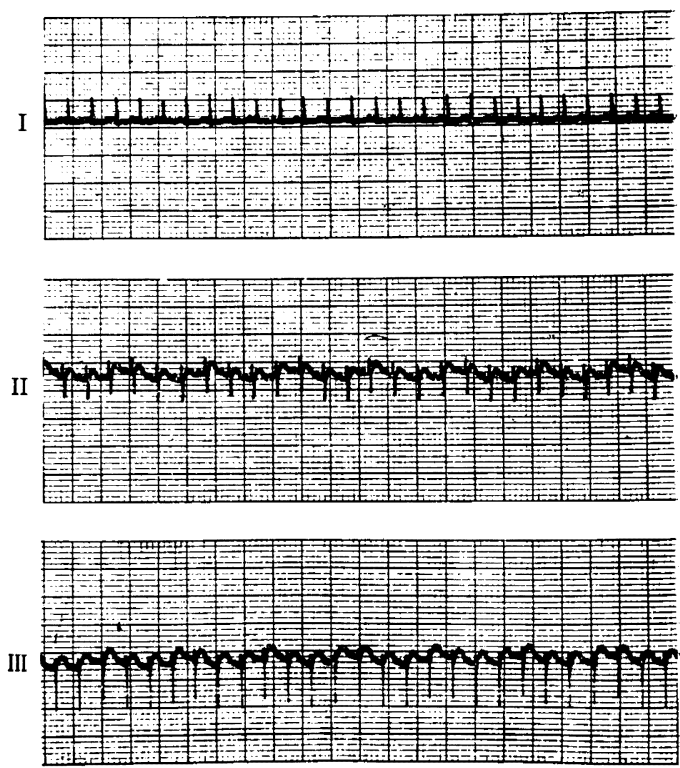

Fig. 3. Electrocardiograms of rat under the $S$ deflection ( $5 \mathrm{hr}$ and $25 \mathrm{~min}$ later).

I : the first lead, II : the second lead, III : the third lead, voltage : $1 \mathrm{mV}$, velocity : $25 \mathrm{~mm} / \mathrm{sec}$. 
バイドを投与したラットに約 4 時間光照射を行ない，心 電図, 体温, 呼吸数の測定を開始した。Fig. 6,7 は心 電困, 呼吸数の測定結果を示す。心電困所見, 呼吸数,

\section{I}

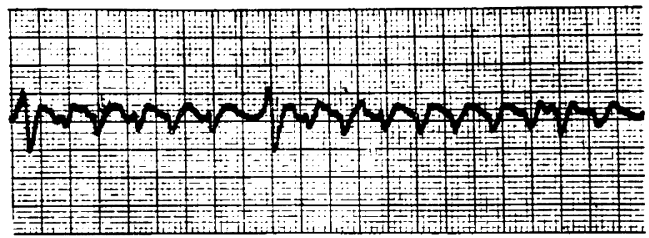

II
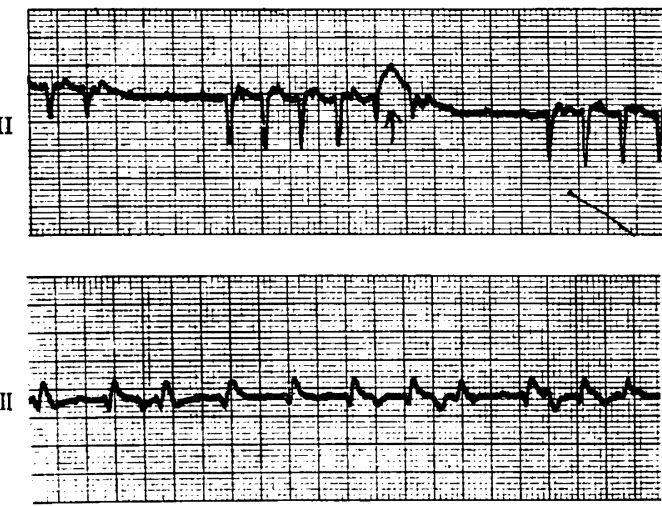

Fig. 4. Electrocardiograms of rat under the atrioventricular block $(5 \mathrm{hr}$ and $30 \mathrm{~min}$ later).

I : the first lead, II : the second lead, IIII : the third lead, voltage : $1 \mathrm{mV}$, velocity : $25 \mathrm{~mm} / \mathrm{sec}$.
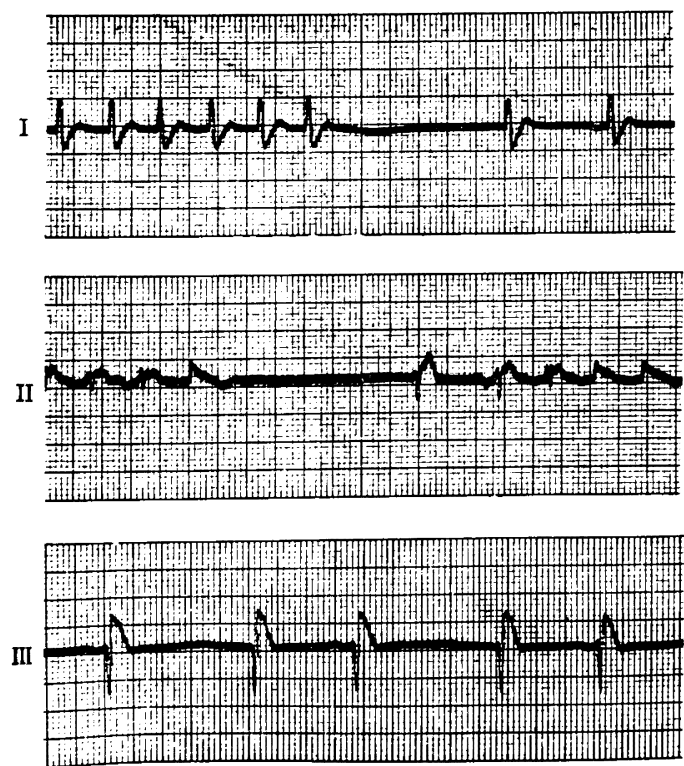

Fig. 5. Electrocardiograms of rat under similar Hyperkalemia (before death).

I : the first lead, II : the second lead, III : the third lead, voltage $: 1 \mathrm{mV}$, velocity $: 25 \mathrm{~mm} / \mathrm{sec}$.
体温ともに，光過敏症は軽度でやや回復傾向が認められ たが，Fig. 7 の矢印の時期で再び約 30 分間の光照射を 行なったところ，Fig. 8 亿示すごとく特丵的な心電龱変 化が出現し, 呼吸数も減少, ラットは約 30 分後に死亡し た。明らかに，光照射中断前と光照射後の心電図には， 時間的な因子以外に光照射といら因子が重要な役割りを 演していることが確認された。

\section{2. 血清電解質の検討}

上記，心電図撮影の結果，光過敏症ラットに护著

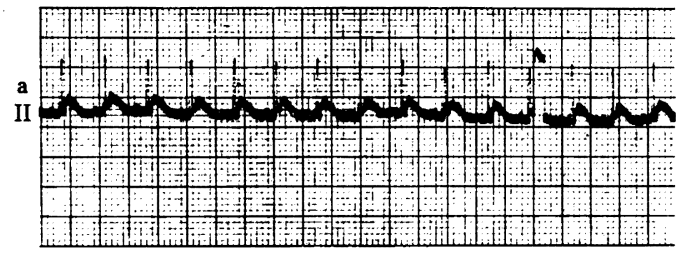

Fig. 6. Electrocardiogram of rat under the experiment 2).

a : before photoirradiation, II : the second lead, voltage : $1 \mathrm{mV}$, velocity : $25 \mathrm{~mm} / \mathrm{sec}$.

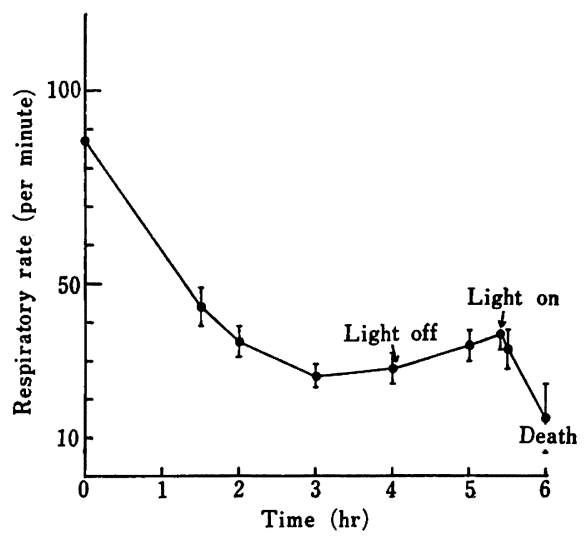

Fig. 7. Changes of respiratory rate (experiment 2).

Symbols indicate the geometrical mean and S.D. of three rats.

b

II

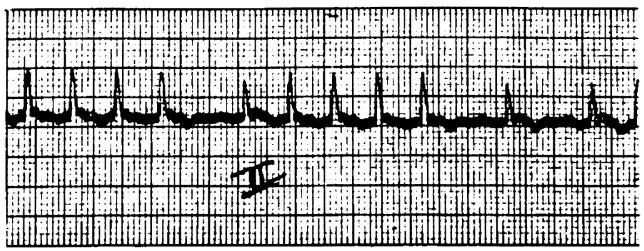

Fig. 8. Electrocardiogram of rat under the experiment 2).

$\mathrm{b}$ : after photoirradiation, II : the second lead, voltage : $1 \mathrm{mV}$, velocity : $25 \mathrm{~mm} / \mathrm{sec}$. 
Table 1. Quantitative analysis of serum electrolytes.

\begin{tabular}{lcccccc}
\hline & $\mathrm{Na}$ & $\mathrm{K}$ & $\mathrm{Cl}$ & $\mathrm{Ca}$ & $\mathrm{P}$ & $\mathrm{Mg}$ \\
\hline Control & $136 \pm 8.3 \dagger$ & $5.3 \pm 0.22$ & $102 \pm 15$ & $9.9 \pm 0.97$ & $7.9 \pm 0.9$ & $3.7 \pm 0.3$ \\
Sample & $133 \pm 6.8$ & $6.9 \pm 0.24$ & $100 \pm 13$ & $9.7 \pm 0.93$ & $11.6 \pm 0.5$ & $3.4 \pm 0.4$ \\
\hline \hline
\end{tabular}

$\mathrm{Na}, \mathrm{K}, \mathrm{Cl}: \mathrm{mEq} / l, \mathrm{Ca}, \mathrm{P}, \mathrm{Mg}: \mathrm{mg} / \mathrm{d} l$, $+:$ mean \pm S.D. (5 rats).

明な心筋障害が確認されたが，その原因の1つとして血 清電解質の異常が推定された。そこで，光過敏症ラット における血清電解質の測定を行なった。

Table 1 にその結果を示す。ナトリウム, 塩素, カル シウムおよびマグネシウム值については，正常ラットの それに比較し，有意の美は認められなかった。しかしな がら，光過敏症のラットにカリウム, リンの上昇がみら れた。カリウム, リンの上昇には溶血の影響が考えられ るが，採血は腹大動脈から太い19G 注射針で注意深く 行ない，採血時の溶血は考えられない。このカリウムの 上昇は心電図所見とよく合致し, 光照射後一定時間後に カリウムの上昇が進行し，心電図にみられるよらな影響 を心筋に及ぼした可能性がある。また，DMSO 単独で は腹水詝留は認められないが，へオホーパイト (DMSO に溶解）では著明な腹水詝留がみられた。光過敏症によ り死亡したラットには, 体重の約 $2.5 \%$ に相当する腹水 が眝留した。この腹水貯留は循環血液量の約 $30 \%$ に当 り，短時間にこれだけの腹水貯留をきたしたことは， へ オホーハイド投与後の光照射が, ラットの体液中の電解 質の濃度異常をむたらすような变化を生しさせたことを 強く示唆している。
要 約

ヘオホーパイドという光過敏症原因物質による光過敏 症のメカニズム探究の一端として, 今回は, 短時間で死 亡するといら事実をるとにして心電図撮影を試みた。

その結果, 重篤な不整眽による死亡であることが確認 され，さらに，不整脈を惹き起こす原因については，血 清電解質のらちのカリウムの上昇がすっとも大きいと考 えられる。すなわち, カリウムフンバランスが1つの要 因になっていることは確実であろらと思われる。

また, 同時に観察された体温下降，腹水館留等も光過 敏症ラットに拈ける異常所見として重要と考えられる。

\section{文献}

1）礒部明彦, 木村修一：栄盖と食糧, 29, 221 (1976)

2) 礒部明彦, 木村修一：栄養と食糧, 29, 225 (1976)

3) Nakamura, K. and Suzuki, K.: GANN, 60, 483 (1969)

4）奥木 実: 実験動物 “取り扱いと実験手技”, 162 (1962), 南山堂

5）緒方英世, 広井 功 : 分析化学, 8, 21 (1959)

6) 金井 泉: 臨床検査法提要, IX-21 (1962), 金原 出版

7）奥木 実: 実験動物 “取り扱いと実験手技”，174 (1962), 南山堂

(昭和51年 6 月 14 日受理) 